ppi $201502 Z U 4645$

Esta publicación cientifica en formato digital es continuidad de la revista impresa ISSN-Versión Impresa 0798-1406 / ISSN-Versión on line 2542-3185Depósito legal pp

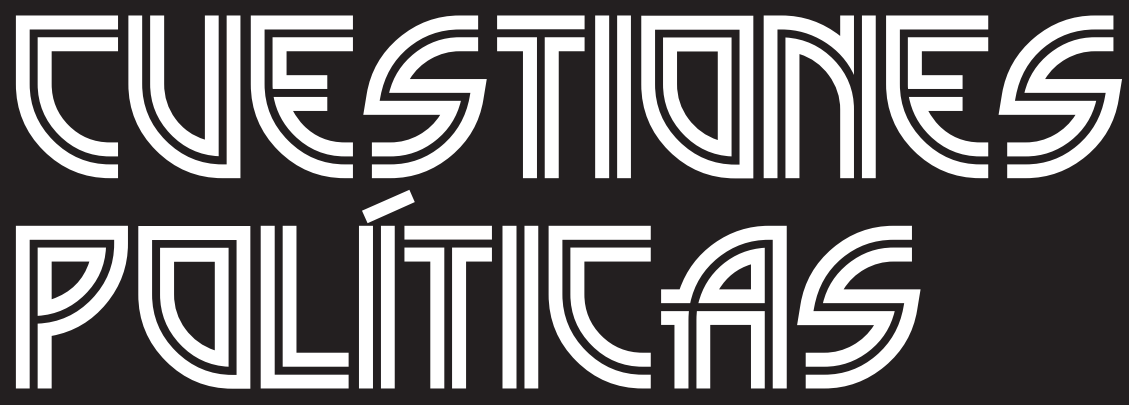

Instituto de Estudios Políticos y Derecho Público "Dr. Humberto J. La Roche' de la Facultad de Ciencias Jurídicas y Políticas de la Universidad del Zulia Maracaibo, Venezuela
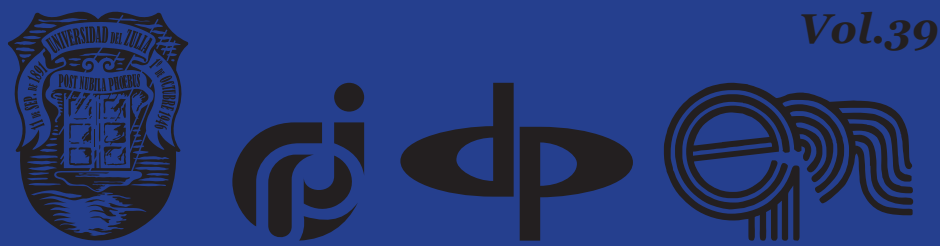


\title{
Online mediation due to the quarantine caused by COVID-19 Pandemic
}

\author{
DOI: https://doi.org/10.46398/cuestpol.3968.59
}

\author{
Denys Dontsov * \\ Andrii Neugodnikov ** \\ Oleksandr Bignyak *** \\ Olena Kharytonova **** \\ Liydmyla Panova *****
}

\begin{abstract}
The institute of mediation is becoming increasingly popular. This is due to several factors, including the possibility to save on attorneys' fees and court costs. Mediation also helps to save a lot of time and find a solution to the conflict that would satisfy both parties as quickly as possible. During the pandemic, the institution of mediation, like many other spheres of public life, moved online. The mediation process itself involves individuals who use online communication or even artificial intelligence, such as chatbots. Thus, in connection with the transition of mediation to the online plane, there is a need for legal support for the use of innovative technologies in the field of mediation. Thus, the article is relevant and timely in terms of quarantine restrictions. The object of research is public relations in the field of online mediation. The authors of the article used general and special research methods. The authors of the article concluded that online mediation is a useful institution, but the implementation of appropriate procedures must take care to protect private information, as there is no full control over the situation outside the camera of a computer, tablet, phone, or other device
\end{abstract} with access on the Internet.

* Ph.D. in Law, Judge of the Primorskyi District Court of Odesa, Ukraine. ORCID ID: https://orcid. org/oooo-0o03-1567-334X. Email: dontsovd@gmail.com

** Ph.D. in Law, Associate Professor, Dean of the Faculty of International Legal Relations of the National University "Odessa Law Academy". ORCID ID: https://orcid.org/oooo-00o2-5121-5365. Email: aaneugodnikov@gmail.com.

*** Doctor of Legal Science, Professor, Head of the Department of International and European Law of National University «Odesa Law Academy». ORCID ID: https://orcid.org/oooo-0002-4079-9940. Email: department.point@ukr.net

**** Doctor of Legal Science, Professor of Intellectual Property and Corporate Law Department and Head of same Department at National University "Odesa Law Academy". Corresponding Member of National Academy of Law Sciences of Ukraine. Honored Science and Technology Worker of Ukraine. ORCID ID: https://orcid.org/oooo-0002-9681-9605. Email: lh2512@gmail.com

****** Ph. D., Associate Professor of Civil Law Department, Taras Shevchenko National University of Kyiv, Address, Kyiv, Ukraine. ORCID ID: https://orcid.org/oooo-ooo2-9524-7529. Email: LPanova@i.ua 
Keywords: alternative dispute resolution, online mediation, peaceful dispute resolution procedure, information technology, mediator.

\section{Mediación online en la cuarentena provocada por la pandemia COVID-19}

\section{Resumen}

El instituto de mediación es cada vez más popular. Esto se debe a varios factores, incluyendo la posibilidad de ahorrar en honorarios de abogados y costos judiciales. La mediación ayuda a ahorrar tiempo y a encontrar una solución al conflicto que satisfaga a ambas partes. Durante la pandemia, la institución de la mediación, como muchas, se desarrolló en la web. El proceso de mediación en sí involucra a individuos que utilizan la comunicación en línea o incluso la inteligencia artificial, como chatbots. Así, en relación con la transición de la mediación al plan online, es necesario un apoyo jurídico para el uso de tecnologías innovadoras en el ámbito de la mediación. Por lo tanto, el artículo es relevante en términos de restricciones de cuarentena. El objeto de la investigación es el estudio de las relaciones públicas en el campo de la mediación en línea. Los autores utilizaron métodos de investigación generales y especiales. Se concluye que la mediación en línea es una institución útil, pero la implementación de procedimientos apropiados debe tener cuidado de proteger la información privada, ya que no hay un control total sobre la situación fuera del ordenador, tableta, teléfono u otro dispositivo con acceso a Internet.

Palabras clave: resolución alternativa de disputas; mediación en línea; procedimiento pacífico de resolución de disputas; tecnología de la información; mediador.

\section{Introduction}

According to the analysis of the duration of civil disputes by the courts of Ukraine, the average duration of a case lasts a year (The Supreme Court of Ukraine, 2019). Through mediation, the term does not exceed 4 months. One of the best international examples of the use of mediation in the 2oth century is the resolution of the Egyptian-Israeli conflict over the ownership of the Sinai Peninsula in 1978. Israel's main interest was to maintain its security, as revealed in the mediation process. For Egypt, on the other hand, there was the preservation of historic territories. After the application of the tool, the peninsula remained a neutral territory (Kriesberg, 2001). 
Mediation is an alternative out-of-court dispute resolution with a high level of efficiency, reaching 90\% worldwide. The quarantine caused by the COVID-19 pandemic has facilitated the peaceful settlement of disputes through mediation. Quarantine measures forced mediators to provide their services online. Online mediation is transforming alternative dispute resolution methods.

It should be stated, that according to the part 5 of Art. 55 of the Constitution of Ukraine (1996), everyone has the right by any means not prohibited by law to protect their rights and freedoms from violations and unlawful encroachments. For today, according to the Concept of Improving the Judiciary for the Establishment of a Fair Court in Ukraine (2006), one of the tasks of the concept is to create opportunities for the development of alternative (out-of-court) ways of resolving disputes.

At the legislative level, the concept of "mediation" is enshrined in the Regulations on free primary legal aid in the Administration of the State Service for Special Communications and Information Protection of Ukraine, approved by the order of the Administration of the State Service for Special Communications and Information Protection of Ukraine from May 4, 2016, No. 320, and means the activities of professional mediators who direct the parties to a legal dispute to compromise and settle the dispute independently by the participants themselves. It should be noted that Ukraine is moving towards the harmonization of its legislation with the legal framework and the recommended EU standards (Pavlova, et al., 2020).

That is, in the legislation of Ukraine there is a definition of the concept of mediation, and the grounds for resolving the dispute are different from those provided for in Art. 432 of the Civil Code of Ukraine (2003), however, insufficient attention is paid to the use of online mediation and the use of information technology, and therefore there is an urgent need to investigate this issue in more detail. The article examines the introduction of online mediation at governmental level, the promotion of this method of resolving disputes in various spheres of public life, as well as the problems faced by mediators in carrying out their activities around the world.

\section{Methodology of the study}

To study the features of the use of information technology in mediation and the use of online mediation, the following research methods were used: dialectical method, method of generalization, comparison, logical methods, modeling method, and method of abstraction.

Thus, firstly, thanks to the dialectical method, the institute of mediation was analyzed during its development, as well as to investigate how this institute developed in resolving disputes in the field in various 
fields. Moreover, the generalization method brought together the general theoretical aspects of the use of mediation in Ukraine and the world and the problematic aspects faced by the parties during this process. Further, the method of comparison made it possible to compare online mediation in resolving disputes in Ukraine and abroad, highlight the features and draw attention to the positive experience of foreign countries in the use of online mediation in resolving disputes.

It should be noted that the method of analysis allowed to single out general theoretical aspects and problematic issues of application of online technologies in resolving disputes through mediation. Thus, the public relations that arise during the settlement of disputes through mediation, Ukrainian legislation, and draft laws on the subject, the case-law of Ukraine, as well as the international experience of using online mediation in dispute resolution were analyzed. This allowed us to conduct a comprehensive study and achieve the goal of the article.

The synthesis method was used to study certain aspects of the relationship that arise, change, and end during the resolution of disputes through online mediation and then combine them into a single whole. Using logical methods, conclusions were drawn on the problematic issues of mediation in resolving disputes in various areas of law and clarified with the help of general problems inherent in mediation as an institution, the problem of using mediation in resolving disputes in intellectual property.

The method of analogy allowed to analyze alternative dispute resolution and the place of online mediation, as well as the use of mediation in different areas of law, in order to understand the difficulties that arise in the same conditions when resolving disputes using a mediator. The modeling method allows simulating disputes that would be appropriate in Ukraine to resolve with the help of a mediator and to draw conclusions about what is necessary for the successful implementation of the mediation procedure in Ukraine.

Using the method of abstraction, mediation was studied as an institution of alternative dispute resolution without taking into account the Ukrainian conditions of its operation. When writing the article, the following regulations were analyzed: The Constitution of Ukraine (1996); Civil Code of Ukraine (2003); Draft Law "On Mediation" (2020); The concept of improving the judiciary to establish a fair court in Ukraine following European standards (2006), and; Regulations on the provision of free primary legal aid in the Administration of the State Service for Special Communications and Information Protection of Ukraine (2016). 
Denys Dontsov, Andrii Neugodnikov, Oleksandr Bignyak, Olena Kharytonova y Liydmyla Panova

918

Online mediation due to the quarantine caused by COVID-19 Pandemic

\section{Analysis of recent research}

The following researchers studied the topic of using information technologies during mediation: Sidoryshyna (2019), Markov (2014), Moroz (2020), Romanadze (2020), Polishchuk (2020), Mykhailenko (2019), Kossak and Yakubovsky (2007), Logvinenko (2019), Motuzka and Samelyuk (n.d.), Ostrovska and Finko (2018), and Starovoitova (2020).

Thus, Sidoryshyna (2019) considered mediation as a new feature of communication in her article. She reviewed the basic techniques of mediation, highlighted the differences between mediation and negotiation, and analyzed the consolidation of mediation at the legislative level. In addition, the article emphasizes the positive experience abroad. The scientist came to the conclusion that even today (without the current law) mediation in Ukraine is often used as a way to reconcile the victim and the offender, to protect consumer rights, to resolve labor and family disputes.

Moreover, Moroz (2020) studied the peculiarities of the use of mediation in resolving disputes between participants in a legal entity. The scholar emphasizes that the use of alternative dispute resolution methods is associated with the imperfection and inefficiency of the national judicial system. Besides, the article discusses in detail the concept of mediation, the principles on which it is based, the benefits of mediation. Particular attention is paid to the person of the mediator and the mediation agreement.

Further, Romanadze (2020) carefully analyzed online mediation between business entities, namely, drew attention to additional challenges for the parties and the mediator. In addition, Markov researched sports mediation and its prospects. Polishchuk (2020) analyzed in detail the use of Zoom, and online platforms in general, for online mediation. Also, Mykhailenko (2019) studied the peculiarities of the mediation online or by phone, its advantages, and disadvantages.

The book of Kossak and Yakubovsky (2007) became the basis for the study of intellectual property law. Thus, the authors have developed definitions of intellectual property rights, including the objects of intellectual property rights, which are most often disputed, which allowed a comprehensive and comprehensive study of dispute resolution in the field of intellectual property. Logvinenko (2019) analyzed the peculiarities of the gradual implementation of mediation in the field of intellectual property and drew attention to its peculiarities in Ukraine. The author's work helped to draw comprehensive conclusions about the peculiarities of the introduction of mediation in Ukraine.

Also, Motuzka and Samelyuk (n.d.) analyzed extrajudicial methods of resolving disputes in the field of intellectual property. Ostrovska and Finko (2018) considered mediation in 2 aspects, namely as an alternative way of resolving conflicts and as a consulting service. In turn, Starovoitova (2020) 
explored in which areas of intellectual property mediation is most effective. Unfortunately, the issue of online mediation has not been sufficiently studied in the literature, so there is an urgent need to conduct research on the use of information technology in mediation.

\section{Results and discussion: general provisions on mediation}

The institute of mediation is part of civil and civil procedure legislation. At the same time, it should be remembered that civil law contains the vast majority of dispositive rules. This is a system of legal norms that gently affect the participants in public relations, giving the latter the right to independently choose the most acceptable option for streamlining the relationship between them (Tkalych, et al., 2020).

Basic principles of mediation: voluntariness, confidentiality, the neutrality of the mediator, responsibility of the parties, mutual respect and equality of the parties, openness of the result. Conflict from the point of view of mediators is an opportunity to see the crisis situation from the other side. Statistics in the world show that $85 \%$ of conflicts are resolved through a mediation tool and only $15 \%$ - when they go to court. As long as the parties are left with negative and conflicting emotions, the mediation process cannot end.

First of all, we will provide a brief overview of the key points related to the mediation process. For ease of perception of the main theses, they are combined in Table 1.

\begin{tabular}{|l|l|}
\hline When considering a dispute, & $\bullet \begin{array}{l}\text { Be a representative of either } \\
\text { party. }\end{array}$ \\
the mediator cannot: & $\begin{array}{l}\text { Provide legal, consulting and } \\
\text { any other assistance to either } \\
\text { party. }\end{array}$ \\
- & $\begin{array}{l}\text { Carry out the activities of a } \\
\text { mediator during the mediation } \\
\text { procedure to be personally } \\
\text { interested in its results, } \\
\text { including with a person if he } \\
\text { is in a family relationship with } \\
\text { one of the parties, and; } \\
\text { Make public statements } \\
\text { without the consent of the } \\
\text { parties. }\end{array}$ \\
\hline
\end{tabular}


Denys Dontsov, Andrii Neugodnikov, Oleksandr Bignyak, Olena Kharytonova y Liydmyla Panova

\begin{tabular}{|c|c|}
\hline $\begin{array}{l}\text { According to a } 2018 \text { survey, } \\
\text { 90\% of commercial dispute } \\
\text { resolution was achieved through } \\
\text { mediation. In this case, the tool } \\
\text { itself is best used if: }\end{array}$ & $\begin{array}{l}\text { - There is a need or intention to } \\
\text { continue the relationship on } \\
\text { both sides. } \\
\text { - There is a need to reduce time } \\
\text { and effort, and; } \\
\text { - There is some information that } \\
\text { is confidential and cannot be } \\
\text { disclosed to the other party. }\end{array}$ \\
\hline $\begin{array}{l}\text { However, there are situation } \\
\text { when mediation method is not the } \\
\text { suitable one. Thus, it is better not to } \\
\text { use the method: }\end{array}$ & $\begin{array}{l}\text { 1. If the situation is a crisis, and; } \\
\text { 2. When a court decision is } \\
\text { required. }\end{array}$ \\
\hline $\begin{array}{l}\text { Finally, considering the } \\
\text { mediation process, the mediator } \\
\text { usually works with questions on: }\end{array}$ & $\begin{array}{ll}\text { - } & \text { Identification of interests. } \\
\text { - } & \text { Solutions. } \\
\text { - } & \text { Criteria, and; } \\
\end{array}$ \\
\hline
\end{tabular}

Table 1. The key points on mediation process (by authors).

Thus, the rules of law governing the mediation procedure are mostly disposititive. For example the parties to the conflict have the right to independently regulate certain issues of mediation. However, imperative rules of law should establish the status, rights and responsibilities of the mediator or regulate the protection of confidential information.

\subsection{Online dispute resolution procedures in foreign countries}

Mediation is a legal phenomenon that has emerged relatively recently in the United States. However, due to the processes of globalization, the institution of mediation quickly gained popularity in most countries. With regard to the wider context of the development of world processes, it is thanks to globalization, as a deliberate policy of the developed countries of the world, aimed at the gradual integration of economic, political, sociocultural and other systems, that any person can satisfy his needs in any sphere (Shyshka and Tkalych, 2020).

Consider the foreign experience of using online mediation (Table 2): 


\begin{tabular}{|c|c|}
\hline Country & The method of settlement \\
\hline USA & $\begin{array}{l}\text { Online dispute resolution procedures have been in } \\
\text { use in the United States since } 1996 \text { and have become } \\
\text { widespread in the settlement of domain name disputes. } \\
\text { The most striking example is the Uniform Domain Name } \\
\text { Dispute Resolution Policy, (UDRP), developed by ICANN. } \\
\text { UDRP is a transparent global online dispute resolution } \\
\text { process that allows trademark owners to effectively combat } \\
\text { cybersquatting. UDRP is used to resolve disputes between } \\
\text { trademark owners and those who have registered a domain } \\
\text { name for fraudulent purposes (for the purpose of reselling } \\
\text { or illegally using the trademark reputation). In addition, } \\
\text { a single Uniform Mediation Act came into force in the } \\
\text { United States in 2001, bringing together } 2,500 \text { different } \\
\text { laws governing mediation procedures in different states. }\end{array}$ \\
\hline $\begin{array}{l}\text { European } \\
\text { Union }\end{array}$ & $\begin{array}{l}\text { The European Commission has developed the European } \\
\text { Small Claims Procedure (ESCP), which has been in force for } \\
\text { all members of the European Union since January 2oo9. } \\
\text { This procedure is intended for resolving cross-border } \\
\text { disputes in which the amount of the claim does not exceed } \\
200 \text { E Euros. According to the ESCP, settlements are made } \\
\text { in writing using information and telecommunications } \\
\text { technologies (e-mail, videoconferencing, etc.). The } \\
\text { provisions of the ESCP are advisory rather than directive, } \\
\text { and the EU. Member States develop their own legal } \\
\text { rules for online dispute resolution. However, the ESCP } \\
\text { provides a vector that will facilitate the introduction of } \\
\text { online litigation, as well as increase overall confidence in } \\
\text { alternative dispute resolution. }\end{array}$ \\
\hline Asia & $\begin{array}{l}\text { In India, online dispute resolution procedures are in } \\
\text { their infancy, but their use is gradually gaining popularity. } \\
\text { With the enactment of the Information Technology, } \\
\text { E-Commerce, and E-Government Technologies Act in } \\
\text { 20oo, India has acquired a legal basis. Arbitration law has } \\
\text { been amended, and now the Indian Arbitration Act of } 1996 \\
\text { is harmonized with the standards of the UNCITRAL model, } \\
\text { and the Code of Civil Procedure of 19o8 has been modified } \\
\text { to introduce alternative dispute resolution procedures. }\end{array}$ \\
\hline $\begin{array}{l}\text { Russian } \\
\text { Federation }\end{array}$ & $\begin{array}{l}\text { In Russia, online mediation is in its infancy, the } \\
\text { situation is quite similar as in Ukraine. Today, only a small } \\
\text { number of companies provide such a service. }\end{array}$ \\
\hline
\end{tabular}

\section{Table 2. Foreign experience of using online mediation (by authors).}

Thus, the institution of mediation is developing rapidly in all regions of the world. At the same time, it reached it peak in the developed countries of the West. However, in other regions, mediation is also gradually becoming in demand. 
Denys Dontsov, Andrii Neugodnikov, Oleksandr Bignyak, Olena Kharytonova y Liydmyla Panova

\subsection{Virtual mediation today}

Now, let's look at what online mediation is in more detail. Online dispute resolution is a set of methods for resolving disputes (conflicts) using Internet technologies.

Online dispute resolution can be used to resolve a wide range of issues, from interpersonal disputes, including consumer disputes, to interstate conflicts. Online mediation has great potential for resolving conflicts in the field of e-commerce.

A virtual mediation is a process by which the parties can resolve business and any other disputes online without the need for personal presence. Meetings are conducted through video or teleconferences, and any form of filing is facilitated through an encrypted cloud platform available via the Internet.

As for software for online mediation procedures, the leading provider of software solutions for online dispute resolution procedures to date has been the American company SquareTrade, which in 2000 launched its first online service for resolving conflicts between e-commerce market participants. The first client of this company was the eBay auction, and later Amazon.com, Crutchfield, eCost, Buy.com, Woot, Vanns, Abt, etc. Other developers are entering the market, including Qualtrust.

The use of Zoom is also common. Thus, Zoom (an American platform for remote conferencing services) is not a purely legal platform and was designed to facilitate access to hearings. However, there are ways to ensure security. The mediator can select settings that require a password. Moreover, once all the expected parties have joined, the mediator can "block" the meeting so that no additional parties can join.

Dispute resolution through online mediation is very similar to regular mediation. The parties may choose a joint meeting at which introductory statements are made. The mediator then invites the participants to the discussion room. As a rule, in complex commercial disputes, the parties may provide additional evidence or important documents in support of their position. Like the classic type of alternative dispute resolution, online mediation involves both short-term and long-term dispute resolution periods. Also, in some cases, online mediation helps reduce overall tensions and bring the parties closer to solving the problem. If an agreement is reached, the parties can prepare a draft and exchange signatures through Docusign, "DIA" (Ukrainian service), or similar programs. Everything can be done online. In the future, this option may replace mediation in its classic form.

Besides, it is worth noting that online mediation is used successfully in the field of sports law. Sport is a special area of public relations. Modern 
sport is a complex system consisting of many levels, one of the main of which and the most dynamically developing is commercial sport (Kharytonov et al., 2021). However, currently, the legal support for professional sports remains at a very low level (Tkalych, et al., 2019). Thus, the mediation procedure gives the athlete obvious advantages: efficiency (agreements reached voluntarily, usually performed according to the laws of conscience and honor), confidentiality (secret "agreements" of the athlete do not apply to the general public), equality (mediation takes into account fair equality, hence the protection of the interests of the weak side in the dilemma of "athlete-federation" and other benefits for athletes.

Thus, the pandemic has affected the work of the courts, which are also taking measures to protect court visitors, judges, and court staff from the spread of the virus. The increase in the number of disputes between business entities due to improper fulfillment of obligations and certain restrictions on the access of citizens to the courts due to the quarantine, lead to an increase in demand for the use of out-of-court online methods of conflict resolution. Thus, online mediation is becoming increasingly popular among businesses, which can be successfully carried out in quarantine. However, any remote mediation is an additional challenge and responsibility for the mediator and the parties to the mediation.

\section{Conclusions}

Therefore, the regulation and application of online mediation in Ukraine are a rather difficult, but quite real procedure.

First, to conduct such mediation, in addition to the mediaability of the case and the intention of the parties to resolve the dispute through mediation, the participants must have the technical ability to participate in meetings via the Internet - a computer, smartphone, or another gadget, the Internet speed enough for quality communication and minimal knowledge to download the necessary program and connect to online meetings.

Secondly, the mediator has an additional burden and responsibility. The mediator needs:

- talk to the parties about more aspects related to the specifics of online mediation.

- solve more organizational issues (assessment of the realism of online mediation, determination of a convenient platform for online meetings, technical support of the parties for downloading and using the online platform (if necessary), organization of visualization, etc.).

- hold preliminary technical meetings with the parties to test the quality of communication. 


\section{Denys Dontsov, Andrii Neugodnikov, Oleksandr Bignyak, Olena Kharytonova y Liydmyla Panova

- keep in focus more issues (in particular, to ensure the technical and psychological comfort of the parties to mediation).

Third, the key to the success of mediation is the trust of the parties trust in the procedure, the trust of the parties to each other, and trust in the mediator. In online mediation, the issue of establishing trust requires the special attention of the mediator and additional time. Mediation is a voluntary procedure, and no person can be forced to participate in mediation. Only the presence of trust can determine the party's consent to participate in mediation.

The issue of maintaining confidentiality also needs special attention in online mediation. The mediator (as well as the parties) cannot be sure that there are no persons who are not participants in the mediation. It is not possible to make sure that participants do not record audio or video or broadcast the meeting online. The issue is resolved by emphasizing the parties 'additional attention to the importance of maintaining confidentiality, open discussion of probable risks, and the parties' trust in each other.

\section{Bibliographic References}

KHARYTONOV, Evgen; KHARYTONOVA, Olena; KOSTRUBA, Anatolii; TKALYCH, Maksym; TOLMACHEVSKA Yuliia. 2021. "To the Peculiarities of Legal and Non-Legal Regulation of Social Relations in the Field of Sport” In: Retos. No. 41, pp. 131-137.

KOSSAK, Volodymyr; YAKUBOVSKY, Ihor. 2007. Intellectual property law. Istina. Kyiv, Ukraine.

KRIESBERG, Louis. 2001. "Mediation and the Transformation of the IsraeliPalestinian Conflict” In: Journal of Peace Research. Vol. 38, No. 3, pp. 373-392.

LOGVINENKO, Mykhailo. 2019. "Features of the gradual implementation of mediation in the field of intellectual property: prospects for Ukraine" In: Theory and practice of intellectual property. Vol. 6, pp.100-108.

MARKOV, Sergey. 2014. "Sports mediation: experience and prospects. Arbitration court" Vol. 1, No. 91, pp. 149-156. Available online. In: https://www.researchgate.net/publication/330245415_Sportivnaa_ mediacia_opyt_i_perspektivy. Consultation date: 23/05/2020.

MOROZ, Svitlana. 2020. The use of mediation in resolving disputes between participants of a legal entity. LigaZakon. Available online. In: https:// uz.ligazakon.ua/ua/magazine_article/EAoo8614. Consultation date: 23/05/2020. 
MOTUZKA, Kateryna; SAMELYUK, Oleksandra. n.d. Extrajudicial methods of dispute settlement in the field of intellectual property. Available online. In: http://maup.com.ua/assets/files/expert/3/6.pdf. Consultation date: 23/05/2020.

MYKHAILENKO, Iana. 2019. Mediation online or by phone. Loyer Hunt. Available online. In: https://loyer.com.ua/uk/onlajn-mediatsiya-abomediatsiya-po-telefonu/. Consultation date: 23/05/2020.

OSTROVSKA, Olena; FINKO, Oleh. 2018. "Mediation as an alternative way of resolving conflicts and consulting service" In: Mykolayiv National University named after V.O. Sukhomlinskyi. Vol. 21, pp. 34-38. Available online. In: http://global-national.in.ua/archive/21-2018/8.pdf. Consultation date: 23/05/2020.

PAVLOVA, Yuliia; POLUNINA, Olha; TKALYCH, Maxym; MANKOVSKYI, Volodymyr; ZUBAIR, Akhmad. 2020. "International-legal standards of cooperation of ukraine in the field of environmental (climate) problems" In: Amazonia Investiga, Vol. 9, No. 25, pp. 295-301. Available online. In https://amazoniainvestiga.info/index.php/amazonia/article/ view/1069. Consultation date: 23/05/2020.

POLISHCHUK, Viktoriia. 2020. Using Zoom for online mediation. Mediation Europe-Asia. Available online. In: https://mediation-eurasia.pro/ blogi/ispolzovanie-zoom-dlya-onlajn-mediacii. Consultation date: 23/05/2020.

ROMANADZE, Luiza. 2020. Online mediation between businesses: additional challenges for the parties and the mediator. Annual scientific-practical conference, pp. 282-284. Available online. In: http://dspace.onua.edu.ua/bitstream/handle/1130o/12862/ Романадзе\%20Л.\%20Д.\%2оОнлайн\%2омедіація\%20між\%20 суб'єктами\%2огосподарювання\%2ододаткові\%2овиклики.... pdf? sequence $=1 \&$ isAllowed $=y$. Consultation date: 23/05/2020.

SHYSHKA, Roman; TKALYCH, Maxym. 2020. "The World in 2020: What Are The Threats To Humanity?” In: Amazonia Investiga. Vol. 9, No. 26, pp. 3-5. Available online. In: https://amazoniainvestiga.info/index.php/ amazonia/article/view/1132. Consultation date: 23/05/2020.

SIDORYSHYNA, Tetiana. 2019. Mediation is a new feature of communication. Legal newspaper. Vol. 38-39. Available online. In: https://yurgazeta.com/publications/practice/inshe/mediaciya--nova-fishkakomunikaciyi.html. Consultation date: 23/05/2020. 
Denys Dontsov, Andrii Neugodnikov, Oleksandr Bignyak, Olena Kharytonova y Liydmyla Panova

STAROVOITOVA, Darina. 2020. Mediation: in which areas is IP the most effective? Legal newspaper online. Available online. In: https://yurgazeta.com/dumka-eksperta/mediaciya-v-yakih-sferah-iv-e-naybilshefektivnoyu.html. Consultation date: 23/05/2020.

TKALYCH, Maxym; SAFONCHYK, Oksana; TOLMACHEVSKA, Yuliia. 2020. "Private Law and human rights: New realities" In: DIXI. No. 32, pp. 1-12.

LAW OF UKRAINE. 1996. Constitution of Ukraine: Law. Available online. In: https://zakon.rada.gov.ua/laws/show/254\%Do\%BA/96\%Do\%B2\%D1\%80\#Text. Consultation date: 23/05/2020.

LAW OF UKRAINE. 2003. Civil Code of Ukraine. Available online. In: https:// zakon.rada.gov.ua/laws/show/435-15\#Text. Consultation date: 23/05/2020.

LAW OF UKRAINE. 2020. On mediation: Draft Law. Available online. In: http://w1.c1.rada.gov.ua/pls/zweb2/webproc4_1?pf3511 $=68877$. Consultation date: 23/05/2020.

LAW OF UKRAINE. ADMINISTRATION OF THE STATE SERVICE FOR SPECIAL COMMUNICATIONS AND INFORMATION PROTECTION. 2016. Regulations on the provision of free primary legal aid: Order 320. Available online. In: https://zakon.rada.gov.ua/laws/show/zo75316\#Text. Consultation date: 23/05/2020.

LAW OF UKRAINE. PRESIDENT. 2006. The concept of improving the judiciary to establish a fair court in Ukraine in accordance with European standards: Decree. Available online. In: https://zakon.rada.gov.ua/laws/ show/361/2006\#Text. Consultation date: 23/05/2020.

LAW OF UKRAINE. The Supreme Court of Ukraine. 2019. Analysis of the duration of civil disputes by the courts of Ukraine. Available online. In: https://supreme.court.gov.ua/userfiles/media/Analiz_KCS_2019_1. pdf. Consultation date: 23/05/2020. 

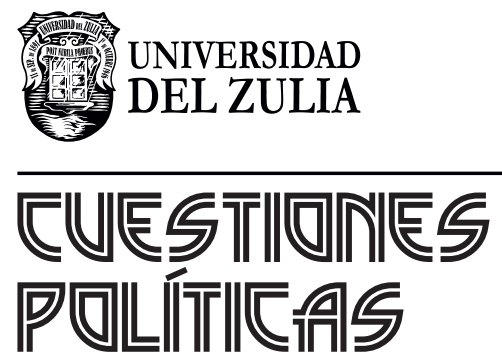

Vol.39 No 68

Esta revista fue editada en formato digital y publicada en enero de 2021, por el Fondo Editorial Serbiluz, Universidad del Zulia. Maracaibo-Venezuela 